\title{
CRISIS OF MEDICAL STAFF EMPLOYMENT WITH HIGHER EDUCATION, MOBILITY IN THE EU AND IMPACT ON REMITTANCES
}

\author{
Valentina VASILE ${ }^{1}$ \\ Elena BUNDUCHI \\ Călin-Adrian COMES $S^{3}$ \\ Ștefan DANIEL ${ }^{4}$
}

\begin{abstract}
Migration of doctors is an important phenomenon, affecting especially less developed EU economies, such as Romania. Data from the past decades highlights constant flows of skilled and highly qualified staff with medical training, migrating to work abroad. Some of them are young graduates, others are already employed on the labour market, which increases the employment deficit in the national medical sector. Starting from the contingents of medical graduates and from the evidence of the College of Doctors in Romania regarding work permits abroad, we will analyze the causes of mobility and, on the other hand, effects, including remittances. The results highlight the need to change the paradigm of health care management, to develop an integrated policy of attracting medical graduates and especially those with higher education to the national labour market.
\end{abstract}

Keywords: medical staff mobility; remittances; health policies

JEL classification: I11, J61, F24

\section{Introduction}

Since the beginning of the century, Romania has experienced a consistent reduction in potential human capital, in several ways:

- migration to work in Europe and worldwide, motivated by higher incomes and better working conditions, but not always jobs correspond to the profile and level of migrant qualification - asymmetric employment with over-qualification;

- increasing the inactivity rate of the working-age population;

- over-qualification in the national economy, present and future demand for the national market, according to CEDEFOP estimates, is mainly directed towards medium or low qualifications and only to a limited extent to higher education (while efforts are being made to increase the share of graduates with higher education - Europe 2020).

Migration of the working-age population is a problem that Romania faces, especially with EU membership. If temporary, short-term migration is viewed both negatively and positively by the authorities, the migration of medical staff is a serious problem. In addition to the fact that doctors usually migrate for long periods of time or permanently settle in the destination country, with no reasons for remittance, there is a shortage of qualified staff in the Romanian medical system.

The causes of medical staff' migration can be analyzed through push-pull factors (Buchan et al, 2006). The motivation for migration appears when there is a large gap between the economic and social push factors in the origin country and pull factors in the destination country. A study by Suciu (et al, 2017) among medical graduates, concludes that $84 \%$ of those interviewed intend to leave the

\footnotetext{
${ }^{1}$ Professor dr., Institute of National Economy, Romanian Academy

2 Teaching Assistant drd., University of Medicine, Pharmacy, Sciences and Technology of Tîrgu Mureş, Romania

${ }^{3}$ Associate Professor dr. University of Medicine, Pharmacy, Sciences and Technology of Tîrgu Mureş, Romania

${ }^{4}$ Associate Professor dr. University of Medicine, Pharmacy, Sciences and Technology of Tîrgu Mureş, Romania

DOI: 10.29302/oeconomica.2018.20.2.9
} 
country immediately after graduation, and $26.5 \%$ of them have already begun negotiations with potential foreign employers. Their arguments for choosing external mobility are higher wages, better working conditions and career advancement, showing disappointment to the Romanian medical system.

In this research we emphasize the particularities of Romania's economic development, which motivates migration and present the characteristics of the health labour market, by highlighting the gaps between labour supply and demand.

\section{Economic development and the level of employment in the Romanian labour market}

Romania is a part of the EU's less developed countries and has a GDP/capita in PPS (2018, Eurostat), which exceeds only Bulgaria's. At the level of the regions of Romania, the differences in development are important, especially in terms of progress in reducing the development gaps. There is a strong asymmetry between the Bucharest-Ilfov region, which is above the EU average and the other regions, of which North-East has the lowest performance.

Table 1.

GDP/capita in PPS, NUTS 2 regions in Romania in 2005-2016, euro

\begin{tabular}{|l|c|r|r|r|r|r|r|r|r|}
\hline & $\begin{array}{c}\text { Ranking } \\
\text { by } \\
\text { GDP/cap }\end{array}$ & $\mathbf{2 0 1 0}$ & $\mathbf{2 0 1 1}$ & $\mathbf{2 0 1 2}$ & $\mathbf{2 0 1 3}$ & $\mathbf{2 0 1 4}$ & $\mathbf{2 0 1 5}$ & $\mathbf{2 0 1 6}$ & $\mathbf{2 0 0 5}$ \\
\hline Noth-West & 4 & 11800 & 11700 & 12600 & 12600 & 13400 & 14300 & 14900 & 1.935 \\
\hline Center & 3 & 12600 & 12800 & 13800 & 13700 & 14100 & 15200 & 15800 & 1.975 \\
\hline Noth-East & 8 & 8100 & 7900 & 9000 & 9100 & 9300 & 9900 & 10400 & 1.962 \\
\hline South-East & 5 & 10600 & 11400 & 12400 & 13100 & 13600 & 13900 & 14500 & 2.042 \\
\hline South Muntenia & 6 & 10700 & 11700 & 11000 & 11500 & 12800 & 12900 & 13400 & 1.971 \\
\hline Bucharest - Ilfov & 1 & 30700 & 33600 & 33500 & 34200 & 35500 & 39200 & 40400 & 2.104 \\
\hline South-West Oltenia & 7 & 10000 & 9900 & 10900 & 10800 & 10800 & 11800 & 12400 & 1.968 \\
\hline West & 2 & 14800 & 15100 & 15400 & 15200 & 15300 & 16900 & 17600 & 1.956 \\
\hline
\end{tabular}

Source: Author's calculation based on Eurostat-Regional gross domestic product (PPS per inhabitant) by NUTS 2 regions. Available at:

http://ec.europa.eu/eurostat/tgm/table.do?tab=table \&init $=1 \&$ plugin $=1 \&$ language $=$ en $\& p c o d e=\operatorname{tgs} 00$ 005

The development disparities registered between Romanian regions and its positioning in the European rankings determines the working age population to migrate in order to obtain a higher wage differential.

Table 2

Estimates of the productive potential of Romania towards the EU 27, at the horizon of 2070

\begin{tabular}{|l|l|l|l|l|l|l|l|}
\hline & $\mathbf{2 0 1 6}$ & $\mathbf{2 0 2 0}$ & $\mathbf{2 0 3 0}$ & $\mathbf{2 0 4 0}$ & $\mathbf{2 0 5 0}$ & $\mathbf{2 0 6 0}$ & $\mathbf{2 0 7 0}$ \\
\hline $\begin{array}{l}\text { The population of Romania aged 25-54, \% } \\
\text { of the total population }\end{array}$ & 42.7 & 42.7 & 37.6 & 33.8 & 32.5 & 32.9 & 33.3 \\
\hline $\begin{array}{l}\text { EU 27, aged 25-54, \% of the total } \\
\text { population }\end{array}$ & 41.3 & 40.0 & 36.6 & 34.8 & 34.0 & 34.0 & 33.9 \\
\hline $\begin{array}{l}\text { The population of Romania aged 15-64, \% } \\
\text { of the total population }\end{array}$ & 67.1 & 65.4 & 63.2 & 58.6 & 55.2 & 54.1 & 55.3 \\
\hline $\begin{array}{l}\text { EU 27, aged 15-64, \% of the total } \\
\text { population }\end{array}$ & 65.3 & 64.1 & 60.9 & 57,9 & 56.1 & 55,7 & 55,9 \\
\hline GDP growth rate - Romania & 3.5 & 3.4 & 2.1 & 1.3 & 1.3 & 1.3 & 1.3 \\
\hline GDP growth rate - EU 27 & 1.3 & 1.4 & 1,2 & 1,2 & 1,4 & 1,5 & 1,4 \\
\hline Employment growth rate (aged 15-74) & 0.1 & -0.2 & -1.4 & -1.1 & -0.8 & -0.4 & -0.3 \\
\hline
\end{tabular}




\begin{tabular}{|l|l|l|l|l|l|l|l|}
\hline Growth rate in hourly labour productivity & 3.6 & 3.8 & 3.5 & 2.4 & 2.1 & 1.8 & 1.5 \\
\hline
\end{tabular}

Source: European Commission, 2017, „The 2018 Ageing Report”, INSTITUTIONAL PAPER 065.

Available at: https://ec.europa.eu/info/sites/info/files/economy-finance/ip065_en.pdf

According to UN (2017) estimates, the population of Romania will decrease (from 19.7 million in 2016 to about 15 million in 2070) and will age. Even with a rising fertility rate from about 1.54 in 2016 to over 1.7 in 2020 and a further 0.1 percentage point increase after 2030 (which is still below the population's simple reproductive rate), the working-age population will decrease through the low birth rate of the remaining and the net loss of potential birth rates of migrants.

Inside the working age population 15-64, the age group between 25 and 54 will drop sharply, from over $63 \%$ in 2016 to below $60 \%$ in 2030 , with no possibility of recovery by the year 2070 , given the fact that the over 65 s almost will double as a share in the total population. Under these circumstances, the importance of new entrants on the labour market will increase, being the ones that could take up newly created jobs as a result of robotization and digitization of economic processes.

Reducing labour supply with the potential to support the modernization / robotization and / or digitization processes of the economy will be important, not necessarily through the inability of the university education system to keep up with the demand for skills and specializations, but especially by losing graduates to the national labour market. The restrictive employment conditions (such as asking "work experience" on hiring), the poor performance of skills acquired through school and the unsustainability of knowledge (many are unnecessary in the business environment or are already outdated) for a professional career guide the graduates to the international markets / market segments of globalized work, more attractive and / or better performing.

The latest estimates show an increased labour migration of higher education graduates in Romania, on average about $40 \%$, but with significant differences in specialization areas, where the share of those who consider the migration option exceeds $3 / 4$ - medicine, services industrial, ICT. Therefore, it is expected that the number of those employed abroad will increase, from over 4 million as at present to around $1 / 4$ of the total population of Romania. Currently, over half of the employed population of Romania is already working abroad (8448777 people in 2016 - INS).

Table 3.

Labour participation estimates of 25-54-year-old population

\begin{tabular}{|l|l|l|l|l|l|l|l|}
\hline Labour participation rate & $\mathbf{2 0 1 6}$ & $\mathbf{2 0 2 0}$ & $\mathbf{2 0 3 0}$ & $\mathbf{2 0 4 0}$ & $\mathbf{2 0 5 0}$ & $\mathbf{2 0 6 0}$ & $\mathbf{2 0 7 0}$ \\
\hline -Total RO (aged 15-64) & 65.6 & 66.7 & 65.5 & 64.2 & 64.7 & 65.4 & 65.0 \\
\hline EU 27 - Total aged 15-64 & 72.3 & 73.1 & 73.9 & 74.1 & 74.3 & 74.4 & 74.4 \\
\hline Total RO - aged 15-24 & 28.2 & 29.1 & 30.0 & 29.0 & 29.2 & 29.1 & 29.1 \\
\hline Total RO - aged 25-54 & $\mathbf{8 1 . 9}$ & $\mathbf{8 1 . 5}$ & $\mathbf{8 1 . 0}$ & $\mathbf{8 1 . 1}$ & $\mathbf{8 1 . 5}$ & $\mathbf{8 1 . 4}$ & $\mathbf{8 1 . 3}$ \\
\hline UE 27 - Total aged 25-54 & 85.4 & 85.8 & 85,9 & 86,0 & 86,2 & 86,2 & 86,3 \\
\hline Total RO - aged 55-64 & 44.0 & 47.5 & 51.5 & 49.9 & 49.7 & 51.4 & 50.7 \\
\hline
\end{tabular}

Source: European Commission, 2017, „The 2018 Ageing Report”, INSTITUTIONAL PAPER 065.

Available at: https://ec.europa.eu/info/sites/info/files/economy-finance/ip065_en.pdf

Population aging will increase the average retirement age and potential, increase labour productivity, but employment will continue to decline and hourly labour productivity will grow at modest rates of about 3.5\%, while the gap with the EU average is extremely high (more than 5 times).

At the same time, it is estimated that the employment rate of those aged 25-54 is slightly reduced, now it is about $82 \%$, again below the EU average.

Estimated performances will generate significant changes in the size and structure of the educational offer, especially for the segment of university education which, in order to meet the 
demand of the labour market, needs to be substantially reformed; we can even say radically: from simply redefining the structure of the trainees by field of specialization, to the level of learning and academic performance. Universities, in order to adapt to demand, will need to reform not only their training areas, but also the level and content of the courses, including learning methods. The flexibility and adaptability of learning content and modern learning methods constitute the stringent priorities of institutional development policies for universities, for adequacy and increased labour market integration.

The number of Romanian university graduates in 2014-2017, persons

\begin{tabular}{|l|r|r|r|r|}
\hline & \multicolumn{1}{|c|}{$\mathbf{2 0 1 4 / 2 0 1 5}$} & $\mathbf{2 0 1 5 / 2 0 1 6}$ & $\mathbf{2 0 1 6 / 2 0 1 7}$ & \multicolumn{1}{|c|}{$\begin{array}{l}\text { Share in total } \\
\text { graduates, \% }\end{array}$} \\
\hline Education sciences & 4730 & 5060 & 6016 & 4,97 \\
\hline Arts and Humanities & 12250 & 11898 & 10973 & 8,63 \\
\hline $\begin{array}{l}\text { Social Sciences, Journalism } \\
\text { and Information }\end{array}$ & 12140 & 11085 & 10474 & 27,68 \\
\hline $\begin{array}{l}\text { Business, Administration and } \\
\text { Law }\end{array}$ & 39625 & 34572 & 33550 & 5,33 \\
\hline $\begin{array}{l}\text { Natural sciences, Mathematics } \\
\text { and Statistics }\end{array}$ & 7768 & 6950 & 6464 & 5,57 \\
\hline $\begin{array}{l}\text { Information and } \\
\text { communications technologies }\end{array}$ & 7142 & 5992 & 6750 & 18,23 \\
\hline $\begin{array}{l}\text { Engineering, Processing and } \\
\text { Construction }\end{array}$ & 22929 & 22098 & 22106 & 4,41 \\
\hline $\begin{array}{l}\text { Agriculture, Forestry, } \\
\text { Fisheries and Veterinary } \\
\text { Science }\end{array}$ & 5471 & 4895 & 5340 & 11,61 \\
\hline Health and social work & 14717 & & & $\mathbf{1 0 0}$ \\
\hline Services & 6706 & 6695 & 5510 & \\
\hline Total & $\mathbf{1 3 3 4 4 7 8}$ & $\mathbf{1 2 1 7 8 8}$ & $\mathbf{1 2 1 2 5 0}$ & \\
\hline
\end{tabular}

Source: Author's calculations based on NIS Tempo Online SCL109H. Available at:

http://statistici.insse.ro/shop/index.jsp?page=tempo3\&lang=ro\&ind=SCL109H

This graduation distribution by field should be highly correlated with the structure of employment in the national economy, adjusted with the regional asymmetry index - respectively the surplus or deficit and by categories of occupations (employees, employers, self-employed and unpaid family workers). Healthcare training ranks 3rd in the hierarchy of graduates' share, which should ensure coverage of the employment deficit, but the higher net benefits that could be obtained from external mobility for work redirects graduate flows to the external labour market and not to the national one. From the perspective of the employment rate of graduates, Romania recorded modest performances (Chart 1).

The gap between Romania and EU27 on graduate employment rate is oscillating and increasing, in divergence from the EU2020 target. The question arises whether it is simply the training asymmetry in relation to the labour market demand or there is more, respectively, the lack of adequate demand for the offer, associated with the decision of the graduates to seek more advantageous jobs on the international labour market, the motivation being double- higher wages and then professional career. 


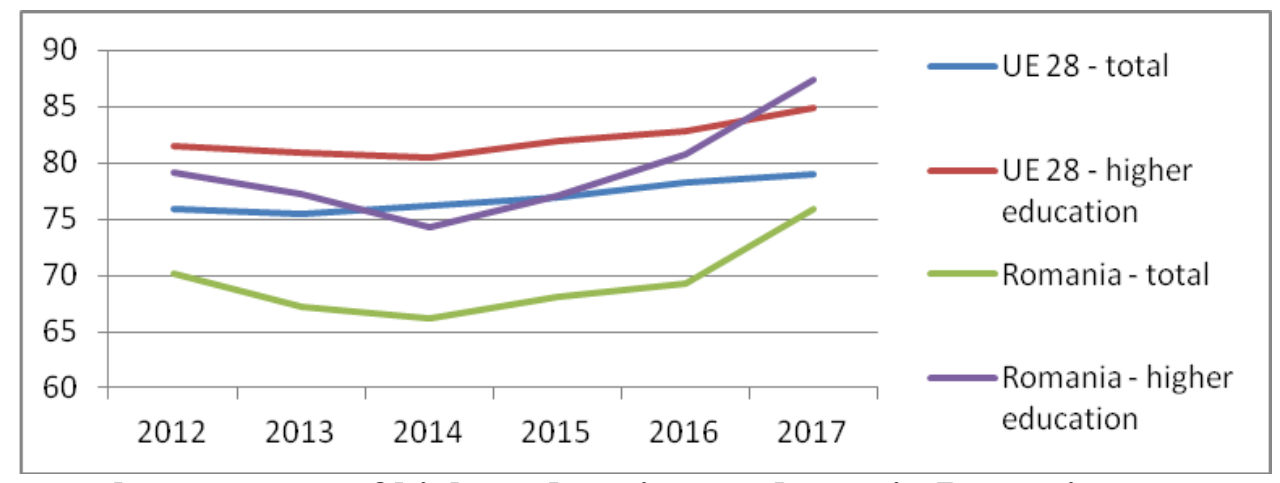

Chart 1. The employment rate of higher education graduates in Romania, compared to the EU average

Sursa: Author's calculation Eurostat Statistics Explained, https://ec.europa.eu/eurostat/statisticsexplained/index.php/Employment_rates_of_recent_graduates\#Employment_rates_of_recent_gradua tes

If we compare with countries like Spain (from the same group of countries with a 60-70\% employment rate), then we can appreciate the relatively more advantageous position of Romania by placing $8.4 \mathrm{pp}$ above the level registered in 2016; but if we take into account the evolution of the last years, then Romania is disadvantaged because the performance is not only reduced on the interval (only $+1.6 \mathrm{pp}$, compared to Spain, which advanced by $3.9 \mathrm{pp}$ in 2016 as compared to 2012) but also oscillating (in 2014 the fall was at 74.2\%). It cannot be motivated by the difficulty of a certain level of performance, because Germany, for example, has progressed on the national total by 1.3 percentage points (from $88.9 \%$ to $90.2 \%$ ) and for the higher education the $93 \%$ threshold, higher than that achieved by Romania by more than $12 \mathrm{pp}$ (Table 5). It is therefore necessary to highlight and analyze in detail the policies of the universities and the support at national level in order to ensure a higher degree of occupation and as soon as possible after graduation.

Table 5.

Employment rate of 20-34 aged in the first 3 years after graduation (\% in total)

\begin{tabular}{|l|l|l|l|l|l|l|}
\hline 2020 EU 28 target=82\% & 2012 & 2013 & 2014 & 2015 & 2016 & $\begin{array}{l}2016 / 2012, \\
(\mathrm{pp})\end{array}$ \\
\hline EU 28-total & 75,9 & 75,5 & 76,2 & 76,9 & 78,2 & $+2,3 \mathrm{pp}$ \\
\hline EU 28 - higher education & 81,5 & 80,8 & 80,5 & 81,9 & 82,8 & $+1,3 \mathrm{pp}$ \\
\hline Romania - total & 69,8 & 67,2 & 65,9 & 68,0 & 69,1 & $-0,9 \mathrm{pp}$ \\
\hline Romania - higher education & 79,1 & 77,2 & 74,2 & 77,1 & 80,7 & $+1,6 \mathrm{pp}$ \\
\hline $\begin{array}{l}\text { Spain (same group with Romania, } \\
\text { 60-70\% national average) }\end{array}$ & 60,4 & 55,9 & 61,1 & 62,2 & 65,6 & $+4,4 \mathrm{pp}$ \\
\hline Spain - higher education & 68,4 & 66,8 & 68,6 & 68,7 & 72,3 & $+3,9 \mathrm{pp}$ \\
\hline Germany & 87,1 & 88,2 & 88,4 & 88,9 & 88,7 & $+1,3 \mathrm{pp}$ \\
\hline Germany - higher education & 93,8 & 94,1 & 93,1 & 93,3 & 93,1 & $-0,7 \mathrm{pp}$ \\
\hline Greece & 42,6 & 39,6 & 44,0 & 45,0 & 49,3 & $+6,2 \mathrm{pp}$ \\
\hline Greece - higher education & 47,7 & 45,4 & 47,4 & 49,9 & 55,0 & $+7,7 \mathrm{pp}$ \\
\hline
\end{tabular}

Source: Author's calculations based on Eurostat data. Available at:

https://ec.europa.eu/eurostat/statistics-

explained/index.php/Employment_rates_of_recent_graduates\#Employment_rates_of_recent_gradua tes 
Although the employment rate of graduates with higher education in the first 3 years of graduation is rising, the vacancy rate is steadily increasing. In the health sector, the vacancy rate exceeds $2.5 \%$ starting in 2016 .

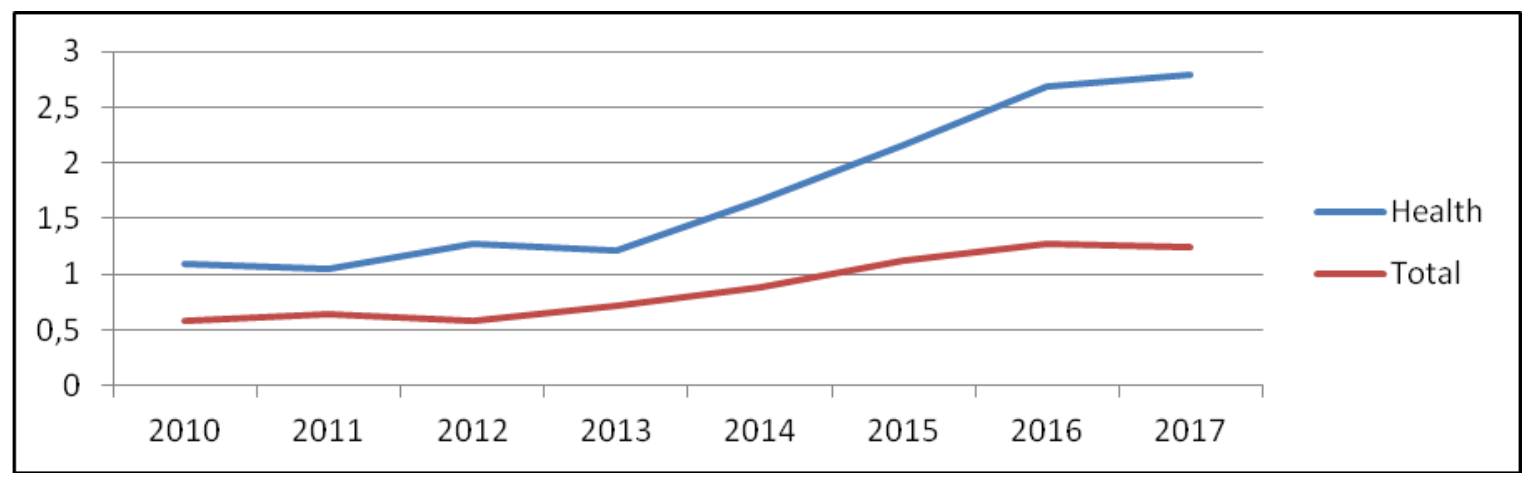

Chart 2. The rate of vacancies in health and social care in 2010-2017

Source: NIS Tempo Online LMV101B. Available at:

http://statistici.insse.ro/shop/index.jsp?page=tempo3\&lang=ro\&ind=LMV101B

It appears that the increase in the number of graduates in the health care sector (bachelor + master + doctorate) has no effect on the jobs vacancy rate. Young people who form themselves in big university centers, but come to practice in small towns hospitals, realize that they can not develop professionally because hospital equipment is missing.

The explanation of this phenomenon may be due to the external migration of young graduates or already employed, being motivated by the wage differential, working conditions, career advancement opportunities. Thus, at the level of 2017, Romania has a deficit of over 50000 doctors and 130000 nurses.

Table 6.

Number of Romanian medical staff in mobility during 2011-2016, persons

\begin{tabular}{|l|l|l|l|l|l|l|}
\hline & $\mathbf{2 0 1 1}$ & $\mathbf{2 0 1 2}$ & $\mathbf{2 0 1 3}$ & $\mathbf{2 0 1 4}$ & $\mathbf{2 0 1 5}$ & $\mathbf{2 0 1 6}$ \\
\hline Physicians & 44547 & 42516 & 41877 & 39559 & 48056 & 50136 \\
\hline Nurses & 118065 & 120267 & 123377 & 126985 & 130908 & 134452 \\
\hline
\end{tabular}

Source: Author's calculations base on Eurostat data - Health workforce migration. Available at: https://ec.europa.eu/eurostat/data/database?node_code=hlth_rs_wkmg

Among the preferred destinations by Romanian physicians, we see: France (4324 doctors in 2016), where the share of Romanian doctors exceeds $17 \%$ of total foreign-trained physicians, Germany (3661 doctors in 2016), holding a share of almost $10 \%$ and UK (1 087 doctors in 2017). The most impressive share is held by nurses working in Italy (11,204 nurses in 2017), more than half of all foreign-trained nurses.

Table 7.

Romanian physicians and nurses in mobility by destination country in 2010-2017, persons

\begin{tabular}{|l|c|c|c|c|c|c|c|c|c|}
\hline $\begin{array}{c}\text { Destination } \\
\text { countries }\end{array}$ & $\mathbf{2 0 1 0}$ & $\mathbf{2 0 1 1}$ & $\mathbf{2 0 1 2}$ & $\mathbf{2 0 1 3}$ & $\mathbf{2 0 1 4}$ & $\mathbf{2 0 1 5}$ & $\mathbf{2 0 1 6}$ & $\mathbf{2 0 1 7}$ & $\begin{array}{c}\text { Mean } \\
\text { wage } \\
\text { diff } \\
\mathbf{2 0 1 6}\end{array}$ \\
\hline Austria & & & & & & & & & $\mathbf{5 . 0 7}$ \\
\hline Physicians (stock) & 16 & 22 & 23 & 31 & 51 & 53 & 51 & 55 & \\
\hline $\begin{array}{l}\text { Share in foreign- } \\
\text { trained physicians }\end{array}$ & 1,2 & 1,6 & 1,5 & 1,9 & 2,7 & 2,7 & 2,5 & 2,5 & \\
\hline
\end{tabular}




\begin{tabular}{|c|c|c|c|c|c|c|c|c|c|}
\hline Belgium & & & & & & & & & 5.40 \\
\hline $\begin{array}{l}\text { Physicians } \\
\text { (stock) }\end{array}$ & 566 & 744 & 866 & 975 & 1064 & 1172 & 1247 & 1300 & \\
\hline $\begin{array}{l}\text { Share in foreign- } \\
\text { trained physicians }\end{array}$ & 12,9 & 14,8 & 15,2 & 15,7 & 15,8 & 17,0 & 16,9 & 16,7 & \\
\hline Nurse (stock) & 298 & 421 & 690 & 888 & 1068 & 1224 & 1329 & 1431 & \\
\hline $\begin{array}{l}\text { Share in foreign- } \\
\text { trained nurse }\end{array}$ & 12,32 & 14,81 & 18,52 & 19,18 & 19,74 & 19,97 & 19,68 & 19,83 & \\
\hline France & & & & & & & & & 4.36 \\
\hline $\begin{array}{l}\text { Physicians } \\
\text { (stock)) }\end{array}$ & & 2726 & 3118 & 3431 & 3734 & 4040 & 4324 & & \\
\hline $\begin{array}{l}\text { Share in foreign- } \\
\text { trained physicians }\end{array}$ & & 15,3 & 16,4 & 16,9 & 17,1 & 17,4 & 17,7 & & \\
\hline Nurse (stock) & 68 & 115 & 147 & 164 & 179 & 193 & 203 & & \\
\hline $\begin{array}{l}\text { Share in foreign- } \\
\text { trained nurse }\end{array}$ & 0,5 & 0,8 & 0,9 & 0,9 & 1,0 & 1,0 & 1,0 & & \\
\hline Germany & & & & & & & & & 5.43 \\
\hline $\begin{array}{l}\text { Physicians } \\
\text { (stock) })\end{array}$ & 1269 & 1840 & 2559 & 3042 & 3363 & 3503 & 3661 & & \\
\hline $\begin{array}{l}\text { Share in foreign- } \\
\text { trained physicians }\end{array}$ & 6,3 & 8,1 & 9,8 & 10,5 & 10,6 & 10,1 & 9,6 & & \\
\hline Ireland & & & & & & & & & 7.19 \\
\hline $\begin{array}{l}\text { Physicians } \\
\text { (stock) }\end{array}$ & & 226 & 286 & 341 & 487 & 625 & 723 & 733 & \\
\hline $\begin{array}{l}\text { Share in foreign- } \\
\text { trained physicians }\end{array}$ & & 3,4 & 4,8 & 5,5 & 7,1 & 7,8 & 7,9 & 7,6 & \\
\hline \multicolumn{10}{|l|}{ Israel } \\
\hline $\begin{array}{l}\text { Physicians } \\
\text { (stock)) }\end{array}$ & 1206 & 1245 & 1252 & 1263 & 1308 & 1389 & 1444 & 1539 & \\
\hline $\begin{array}{l}\text { Share in foreign- } \\
\text { trained physicians }\end{array}$ & 7,8 & 7,9 & 7,9 & 7,9 & 8,2 & 8,6 & 8,8 & 9,3 & \\
\hline Italy & & & & & & & & & 4.98 \\
\hline Nurse (stock) & 10570 & 11215 & 11531 & 11731 & 11820 & 12159 & 11714 & 11204 & \\
\hline $\begin{array}{l}\text { Share in foreign- } \\
\text { trained nurse }\end{array}$ & 46,4 & 47,5 & 48,2 & 48,7 & 49,3 & 50,1 & 50,3 & 50,4 & \\
\hline Sweden & & & & & & & & & 6.09 \\
\hline $\begin{array}{l}\text { Physicians } \\
\text { (stock)) }\end{array}$ & 421 & 485 & 564 & 628 & 735 & 817 & & & \\
\hline $\begin{array}{l}\text { Share in foreign- } \\
\text { trained physicians }\end{array}$ & 4,9 & 5,3 & 5,8 & 6,1 & 6,7 & 6,9 & & & \\
\hline United Kingdom & & & & & & & & & 5.65 \\
\hline $\begin{array}{l}\text { Physicians } \\
\text { (stock) }\end{array}$ & 435 & 582 & 639 & 764 & 852 & 917 & 994 & 1087 & \\
\hline $\begin{array}{l}\text { Share in foreign- } \\
\text { trained physicians }\end{array}$ & 0,9 & 1,3 & 1,4 & 1,6 & 1,7 & 1,9 & 1,9 & 2,1 & \\
\hline Nurse (stock) & & & & & 3759 & 6026 & 8151 & 7732 & \\
\hline $\begin{array}{l}\text { Share in foreign- } \\
\text { trained nurse }\end{array}$ & & & & & 4,1 & 6,0 & 7,7 & 7,5 & \\
\hline
\end{tabular}

Source: Author's calculation OECD (Health Workforce Migration) and Eurostat (Mean monthly earnings). Available at: https://stats.oecd.org/Index.aspx?QueryId=68336\# http://appsso.eurostat.ec.europa.eu/nui/show.do?dataset=earn_ses14_20\&lang=en 
The main motivation of migration and selection of destination countries is the wage differential. Available Eurostat data shows that at the level of 2016, the average wage differential in the health and social care sector was 4-5 times higher than that obtained in Romania.

Table 8 .

The number of medical staff per 100,000 inhabitants

\begin{tabular}{|l|l|l|l|l|l|l|l|}
\hline & $\mathbf{2 0 1 0}$ & $\mathbf{2 0 1 1}$ & $\mathbf{2 0 1 2}$ & $\mathbf{2 0 1 3}$ & $\mathbf{2 0 1 4}$ & $\mathbf{2 0 1 5}$ & $\mathbf{2 0 1 6}$ \\
\hline Romania & & & & & & & \\
\hline Physicians/100000 & 243,51 & 245,69 & 267,63 & 270,65 & 275,90 & 283,16 & 290,85 \\
\hline Nurses / 100000 & 847,51 & 842,02 & 903,54 & 924,43 & 945,93 & 985,45 & 1029,46 \\
\hline Austria & & & & & & & \\
\hline Physicians/100000 & 478,02 & 482,38 & 489,54 & 498,88 & 504,90 & 509,69 & 512,96 \\
\hline Denmark & & & & & & & \\
\hline Physicians/100000 & 383,6 & 387,75 & 390,93 & 392,31 & 392,31 & 394,39 & \\
\hline Nurses/100000 & 2762,34 & 2744,82 & 2764,36 & 2785,82 & 2803,52 & 2814,40 & \\
\hline Belgium & & & & & & & \\
\hline Physicians /100000 & 291,34 & 291,30 & 292,80 & 295,09 & 297,55 & 301,75 & 307,41 \\
\hline Nurses/100000 & 1887,73 & 1978,14 & 2091,71 & 2198,61 & 2317,75 & & \\
\hline France & & & & & & & \\
\hline Physicians/100000 & 327,23 & 330,77 & 331,83 & 332,56 & 333,73 & 333,82 & 334,62 \\
\hline Nurses/100000 & 1450,84 & 1486,43 & 1543,19 & 1584,37 & 1615,52 & 1643,17 & 1675,56 \\
\hline Germany & & & & & & & \\
\hline Physicians/10000 & 406,11 & 416,32 & 423,71 & 436,97 & 449,00 & 452,52 & 457,70 \\
\hline Latvia & & & & & & & \\
\hline Physicians/10000 & 317,84 & 336,41 & 339,33 & 339,55 & 338,30 & 336,13 & 336,92 \\
\hline Nurses/010000 & 579,13 & 615,25 & 605,85 & 612,18 & 609,75 & 597,36 & 593,61 \\
\hline
\end{tabular}

Source: Author's calculation Eurostat (Health care staff). Available at:

http://appsso.eurostat.ec.europa.eu/nui/show.do?dataset=hlth_rs_prs1\&lang=en

http://appsso.eurostat.ec.europa.eu/nui/show.do?dataset=hlth rs prsns\&lang=en

As a result of the increase in the number of Romanian physicians who migrated, health services are provided by only 50136 doctors in the year 2016, although the number of medical graduates is growing. This means that there are 290 doctors on 100000 population.

Physicians in Romania are overwhelmed, aging and concentrated in the big universities centers, forced to deal with old appliances and long lists of patients who, although paying health insurance, do not have a fair access to health services, as is the case with patients from other European countries.

According to Eurostat data, Romania is on the last positions on the number of doctors per 100,000 inhabitants, only Poland and Albania are doing worse (Eurostat, 2018). On the other hand, there are over 500 physicians per 100,000 inhabitants in Austria, 450 doctors per 100,000 inhabitants in Germany, while in Latvia there are more than 336 doctors per thousand inhabitants. As for the number of nurses per 100,000 inhabitants, Romania has only half of the number of other states, around 1,030 nurses / 100000 inhabitants.

\section{Migration and remittance model for medical staff}

The migration and remittance decision can be analyzed from the perspective of the push-pull factors of the economic and social dimensions:

\section{Economic factors}

Push factors

a) Low wages;

b) Impossibility of career advancement;
Pull factors

a) Higher incomes, which would help to reduce the poverty of the family left at home; 
c) Low living standards coupled with b) Possibility to advance in career restrictions on funding opportunities, c) Better living conditions; especially for young families;

\section{Social factors}

Push factors

Higher unemployment rate (Vasile V., 2014). High level of poverty; The impossibility of accessing quality medical services for people in rural areas;

The weakness of the educational system; Lack of public policy measures aimed at Respect for human rights; supporting young graduates;
Low level of poverty;

Ensuring access to high quality medical

services;

Access to higher education institutions;

Political stability.
Pull factors 
the lack of equipment which do not allow the correct fulfillment of the obligations towards the patients (Boncea, 2014) are the main factors that contributed to the medical staff crisis from Romania.

\section{Conclusions}

Migration among medical staff involves the exodus of highly qualified staff, which has an impact on the development and proper functioning of the medical system as well as on the health status of the Romanian population.

The main causes of medical staff migration are:

- The wage differential that they would earn in the destination country compared to the one in Romania. Mostly Romanian doctors chose Western European countries, which earns them a salary 5 times higher than in Romania.

- Poor work conditions associated with the poor equipment of hospitals, especially in rural areas (Tilea et al, 2013).

- Strategy lack on reforming health institutions.

- The lack of a correlation between the competences acquired in the university environment and those required at the workplace.

In order to reduce the migration of medical staff, the authorities should rethink the policy of attracting / retaining doctors and nurses and take into account the following measures:

- The remuneration of medical staff according to performance and efficiency.

- Implementing a strategy in the university environment, which would aim at correlating the necessary skills on the labour market with the gained theoretical knowledge.

- Investments in modern equipment, aiming the reduction of gap between medical institutions in rural and urban areas.

- Providing attractive working conditions for medical staff, especially for attracting and maintaining them in rural areas.

- Skills and knowledge exchange between Romanian and return medical staff (Boboc et al, 2011).

- Facilitating access to internal and external funds, aimed at financing investment projects in equipment and work infrastructure, as well as staff training programs.

\section{References}

1. Boboc, C., Vasile, V., \& Ghiţă, S., 2011, „Migration of Physicians: Causes and Effects in CEE Countries", Education and Management, p.514-520.

2. Boncea I., 2014, „Brain drain in Romania: factors influencing physicians' emigration”, Journal of Community Positive Practices, vol. 14 (1), p. 64-74.

3. Buchan, J., Perfilieva, G., 2006, „Health Worker Migration in the European Region: Country Case Studies and Policy Implications", Division of Country Support WHO Regional Office for Europe, Copenhagen.

4. EC COM (2010) 2020: Europe 2020 A strategy for smart, sustainable and inclusive growth, March 2010 [Online]. Available: http://ec.europa.eu/eu2020/pdf/COMPLET\%20EN\%20BARROSO\%20\%20\%20007\%20\%20Europe\%202020\%20-\%20EN\%20version.pdf

5. Eurostat https://ec.europa.eu/eurostat/data/

6. National Institute of Statistics. http://statistici.insse.ro/shop/?lang=ro

7. OECD. https://stats.oecd.org/

8. Suciu, Ș.M., Popescu C.A., Ciumageanu, M.D., Buzoianu A.D., 2017, „Physician migration at its roots: a study on the emigration preferences and plans among medical students in Romania. Human Resources for Health,, [e-journal], https://humanresourceshealth.biomedcentral.com/articles/10.1186/s12960-017-0181-8 
9. Tilea, B., Vasile, V., Tilea, I. (2013). Labour force mobility and employment crisis in health care sector in Romania. Romanian Journal of Economics, $36(1$ (45)), 30-54.

10. United Nations, Department of Economic and Social Affairs, Population Division (2017). World Population Prospects: The 2017 Revision, Key Findings and Advance Tables. Working Paper No. ESA/P/WP/248.

11. Vasile V., 2014, „Labour mobility impact on sending countries. Romanian EU workers case study", Procedia Economics and Finance, vol. 8, p.737-746. 